Volume 1 Number 2

\title{
NEWSPAPER COVERAGE OF DOMESTIC VIOLENCE AGAINST WOMEN DURING COVID-19 LOCKDOWN
}

\author{
Chinedu Lawrence Ekweonu \\ Department of Mass Communication \\ Nnamdi Azikiwe University \\ Awka \\ Phone:08064768695 \\ LAKASS2007@yahoo.com
}

\begin{abstract}
This study examined the coverage of domestic violence against women in select Nigerian dailies. Among the national dailies under review are Daily Sun, Vanguard and Guardian newspapers. The researcher used the content analysis research method in reviewing the manifest contents of the three papers from March $23^{\text {rd }}$ to June 2020. The study period covered a total of 100 days which translates to 300 publications of the three newspapers under investigation. The specific objectives of the study are to ascertain whether the newspapers give prominence to domestic violence; find the dominant source of interventions for victims of domestic violence against women; observe whether the newspapers gave adequate publications to the rising domestic violence against women and find out if the newspapers actually follow-up domestic violence cases within the lockdown in their publications. The social responsibility and Agenda-setting theories served as the theoretical framework for the study. Findings revealed that the newspapers neither gave prominence nor adequate coverage to domestic violence against women within the lockdown period. It was also found that the newspapers hardly follow-up their stories on domestic violence within the period. The researcher concluded that the select newspapers did not do well in their coverage of domestic violence in the period under investigation by publishing only 115 news items on such crimes within the period. The study recommended among others that the media should as a respect to their social responsibility functions expose the people to the harmful effects of domestic violence against women in the country.
\end{abstract}

Keywords: Domestic violence, Newspapers, Corona virus, Women

\section{INTRODUCTION}

Women form a greater percentage of the population of human population around the globe and as well play significant and varying roles both at home and at their places of work (Sambe, 2015). Unfortunately, this set of people face the highest level of unimaginable inhuman treatment globally, tearfully from their much-needed spouses who are expected to provide for them and protect them from all kinds of harm. On the contrary, their husbands unleash harm on them at every slightest provocation. Violence generally, is a threat to the globe with women and children as the most vulnerable and its outcome highly devastating. Domestic violence against women is a global infestation that transcends boundaries and occurs in all cultures and societies around the world (Albana, 2017).

Culturally, some societies have long historical records of male domination, in which women were mostly taught how to obey their husbands; accept their submissive roles and subscribe to be under their first male children when their husband dies. This is a reflection of the strong patriarchal traditions dominant among the majority of human societies. These traditions and cultures at varying degrees provide the templates for the relegation of the women to the background. This makes domestic violence very common and a global issue of concern. It is widespread; often considered socially acceptable among some cultures and globally underreported. Significantly, the most worrisome situation of universal interest is that women hardly report or disclose physical, sexual and or any other forms of violence especially when 
committed against them by an intimate partner (Sutherland, McCormack, Pirkis, Easteal, and Vaughan 2015). Surveys undertaken in 2012 and 2013 indicated that around 30\% of women had experienced some form of physical, sexual or emotional domestic violence during their lifetime (IAGCI, 2016). Although there seems to be a change in attitude among some societies, recent reports demonstrated a surge in the rate of domestic violence around the globe owing to this lockdown (Wkipedia, 2020; UN, 2020; Lennard, 2020; Townsend, 2020. For instance, the call to helpline in Tunisia increased by fivefold in the first days of the lockdown (Graham-Harrison, Glufrrida, and Ford, 2020). In Uk, the first week of the lockdown witnessed an increase in the number of calls to the helpline by $25 \%$ with $150 \%$ increase in the number of visits to the website (Fraser, 2020). In Cyprus and Singapore, helpline calls increased by $30 \%$ (NDVH, 2020) within the first week of lockdown, $40 \%$ in Australia and $67 \%$ in Argentina (UN women, 2020).

Globally, domestic violence is one of the most pervasive violations of fundamental human rights which affect women of all ages, race, creed and economic backgrounds (Sutherland, McCormack, Pirkis, Easteal, and Vaughan, (2015). It is harm that goes beyond the physical realm and transcends into perpetual emotional feeling leading to torture, severe pains and depressions.

According to WHO (2013) cited in Galvão, (2015), there is a shred of strong evidence establishing links between women's exposure to violence and direct health outcomes. Reports from the review revealed that domestic violence against women could be as dangerous as leading to mental health problems, subscription to substance use, and the desire to commit suicide and harm oneself and unleash fatal and non-fatal injuries on one. Drawing from the above research reports, it can be seen that the effects of domestic violence are enormous and all-encompassing ranging from the individual victims to the entire society where such lifestyles are harboured. Considering the impact of domestic violence, Sutherland, et al. (2015) argues that domestic violence influences the health, welfare and development of individuals and families, the communities in which they live and the entire society as a whole. Generally, domestic violence or violence of any kind is overwhelmingly committed against women by men. Such violence includes direct and indirect threats of physical assault, sexual assault, emotional and psychological torment, economic control, social isolation and any related and similar behaviours that result or can force women to live in perpetual fear (Cripps \& Davis, 2012; WHO, 2013; Sutherland, et al. (2015).

Drawing from the facts provided above on the influence of domestic violence against women to the victims, the families and the larger societies, it is imperative that the mass media must make some moves in exposing the causes of domestic violence and with a view to provide precautionary measures to restrict the surge. Efforts should be geared towards unraveling the underlying causes and at the same time providing primary preventive measures owing to the negative impacts of the menace on the society to restrict the rise in domestic violence. For instance, in Australia and overseas, public policies addressing violence against women are increasingly focused on primary prevention strategies targeted at preventing violence before it occurs (VicHealth, 2007). In the context of addressing violence against women, the target of primary prevention should be to reduce the incidences leading to its occurrence by targeting factors that give rise to or create conditions in which violence against women sets in (Quadara \& Wall, 2012). Against this background, this study will look at the newspaper coverage of domestic violence against women with particular reference to the causes and measures of controlling the menace in the country. 
Although domestic violence had existed long before 2020, it reportedly escalated within this period of lockdown (Wikipedia, 2020; UN, 2020; Lennard, 2020; Townsend, 2020). Perhaps, domestic violence may not be totally absent in any society with the majority of its population, leaving below the poverty line. The state of chronic poverty in Nigeria made it evident that a good number of anti-social acts, such as crimes and violence must be prevalent in the nation within this lockdown because many people were stock in one place with little resources to fend for the family. This fact and several others, such as frequent demand for sex by idle men and high level of incompatibility among spouses forced the domestic violence curve to rise within the lockdown period. In keeping with their social responsibility roles to the less privileged and oppressed as the voice of the voiceless, the press is expected to pick up these unhealthy acts against women; challenge those cultural and social norms that condone, tolerate or excuse violence against women elsewhere in the globe. Drawing from this context, the news and information media are considered as dominant forces that can play significant roles in shaping the discourse on matters of international concern like domestic violence against women.

Unfortunately, how newspapers covered the acts of domestic violence within this Corona virus lockdown period cannot be ascertained without an empirical study of this nature. The attention of the media is needed by the less privileged and oppressed for in the end, the domestic violence victims and survivors shall remember not the voice of their killer-spouses or domestic violence supporting cultures and traditions, but the silence of their friends (the media). Against this backdrop, this study examined newspaper coverage of the domestic violence against women in their various lockdown environments within the virus ravaging period.

\section{RESEARCH OBJECTIVES}

The central objective of this study is to examine the newspaper coverage of domestic violence against women in Nigeria during the global Corona-virus lockdown period. The specific objectives of the study are to:

$>$ Ascertain if the newspapers gave prominence coverage to domestic violence within the lockdown period.

$>$ Determine the dominant source of interventions for victims of domestic violence against women within the lockdown period.

$>$ Observe whether the newspapers gave adequate publications to the rising domestic violence against women within lockdown period.

$>$ Find out if the newspapers actually follow up domestic violence cases within the lockdown period through the frequency of their publications.

\section{DOMESTIC VIOLENCE AND THE MASS MEDIA: A PREVENTIVE APPROACH}

Domestic violence has no generally accepted interpretation because it has different dimensions and perspectives. For the sake of this study, the UN (1993) definition which sees domestic violence as any act of gender-based violence that results in, or is likely to result in, physical, sexual or psychological harm or suffering to women, including threats of such acts, coercion or arbitrary deprivation of liberty, whether occurring in public or private life, was adopted.

From the above definition by the United Nations, it is clear even though men can equally suffer domestic violence (Domestic Violence Death Review Team, 2015), this study is more concerned with media coverage of violence against women within the lockdown 
period in Nigeria. The reason for the high rate of domestic violence in the country is most rooted in the fact that rules are just made in Nigeria only to be violated. Generally, Nigeria has laws guiding against domestic violence, but these laws don't count in the real-time when the need arises (Vanguard News, 2016). What did the law on domestic violence say? How had those who violated the rules been handled in respect to these laws? These are among the duties expected of the media to carry out for the repositioning of the society. Reporting the sections of the laws violated and the consequences of violence against any woman may in the media go a long way in deterring others from taking similar actions against their spouses in the society.

In discussing domestic violence, the mass media are placed on the side of responsibility to deliver the needed views to ensure that the lives and health of the women are set free from domestic violence of any kind. This is because of the media power to shape and manipulate the public opinions and discussions in matters that affect the larger society. This was captured more clearly in Carll (2003) when he argues that the mass media features are seen as the most vibrant priority area in primary prevention of domestic violence because it has the potential influence to guide and shape public understanding of violence against women.

In several studies on the influence of mass media contents on people's perception of issues, efforts have passionately concentrated on the source of the materials; its gatekeepers and the audience. With this, little is known about the structures of the materials in the media and what the structure got to do with the acceptance or rejection of information. It is the structure of the materials that can explain how and why readers of materials are influenced by what they see, read or hear in the media (Sutherland et al. 2015). Considering the why and how of media influence on its audience belief system, Easteal, Holland, \& Judd, (2015) vehemently argued that unquestionably, the way information is structured can increase public understanding of violence against women and, more importantly, challenge its place in society.

\section{EMPIRICAL LITERATURE}

Rollè, Abbà, Fazzino, Marino and Brustia (2014) examined the media represented domestic violence in two (2) none politically aligned Italian-newspapers in the years 2002/12. The study which used the content analysis research method found that there is a preference to generally explain the phenomenon of domestic violence rather than discuss the problem to the society. This finding creates a room for a study of this nature to investigate the media contents in line with providing the extent to which the media showcased the primary causes of domestic violence against women. This will help in tackling the menace if adequately $\mathrm{x}$ rayed.

Owusu-Addo, Owusu-Addo, Antoh, Sarpong, Obeng-Okrahand Annan (2018) adopted media framing in their study on Violence against Women and Girls (VAWG). The survey which sees the women and girls as critical public of the mass media was interested in the public health-related issues that domestic violence can cause in society. The study which focuses on media framing of the problems demonstrated that how the news media cover public health issues is critical for designing effective health promotion interventions. Moreover, this study points to the fact that studies on domestic violence are scarce in low-and middle-income countries of the world. The study adopted the Qualitative content analysis research method in providing the analysis of how Ghanaian media represented Violence against Women and Girls in Ghana with a total of 48 news articles on the study. The findings indicate that media framing of VAWG was episodic in nature. It shows that the victims are primarily the 
that carry the blames from the news articles reviewed. In framing VAWG as an individual incident and women as helpless victims, the media fail to shape society's perception of VAWG as a social and public health issue. The study, therefore, concluded that for the media in Ghana to contribute to the prevention of VAWG, there is the need for news coverage to focus on the social construction of the issue, and also raise awareness about support services available to victims. This study opened a gap for the current one when it argues that there was shortage of literature in studies on media and domestic violence in low income and middle income earning countries. Nigeria is one of the middle if not among the low-income earning countries where domestic violence is rampant.

Daniel, Aniekeme and Nnamdie (2019) examined Uyo Residents' Perception of Selected Newspaper Coverage of Gender-based violence in Nigeria. The study adopted a survey research method investigating the perception of newspaper coverage of domestic violence among 400 respondents. The findings reveal that majority of the respondents $(51.3 \%)$ thought that Daily Sun and Vanguard newspapers do not cover Gender-based violence issues frequently. The researchers recommend that there is need to strategize ways that will facilitate the prominence of Gender-Based Violence stories in the newspapers (like putting GBV stories on the centre spread or front pages) where all genders are well covered and given prominence to aid readers in understanding the issues of GBV. This study is related to the current one, given that it discusses media coverage but differ in the research method. As the previous research is looking at the perception of the audience, the current one is concerned with the efforts of the media in performing their social responsibility and agendasetting function with a view to eradicate evils in the society. This study looked at the frequency and prominence of coverage. At the same time, the current one is concerned with the causes and possible information provided by the media to stop domestic violence against women.

In another study, Yusuf, Arulogun, Oladepo, and Olowokeere (2011) study examined genderbased violence with emphasis on physical violence among men and women in an intimate relationship. The study adopted the survey research method in reviewing a total of 989 respondents sampled through multi-stage cluster sampling procedure conducted around the six geo-political zones of Nigeria. The researchers found that more females experienced physical violence than males. The study recommended that strategies should be put in place, and all major stakeholders should help to curb this menace. The mass media are among the stakeholders in this recommendation. That makes this current study very apt in considering the efforts of the media in finding out the causes of violence and condemning the same for the evil to cease in society.

In a different study, Talabi (2016) examined the dominant frames adopted by the print media in reporting abuses against homemakers. The study adopted the manifest content analysis research method with stories, features articles, opinion articles, editorials and cartoon/graphics as the units of analysis in this study. The findings showed that newspaper actively reported homemakers' abuse incidence, but the tone of editorial bias in most abuse stories portrayed in the newspapers was not given. The study recommends that the newspaper should do more than just creating awareness about homemakers' abuses by mere reportage, but a mediatory and change-stimulating coverage of homemakers' abuse should be done. This recommendation is a wake-up call to this current one which looks at how the media placed their report on the causes of domestic violence and expose all customs, cultures and norms that provide an excuse for committing violence against women. 


\section{THEORETICAL FRAMEWORK}

On the previous scholarly views which have stressed the importance and indispensability of theories in social science research, this study was anchored on two theories, namely- The Social Responsibility and Agenda-Setting theories of mass communication.

\section{Social Responsibility Theory}

The social responsibility theory places the media on the obligation of doing the needful in getting the evils in society and exposing them to see if society can do away with it. By the provision of social responsibility theory, the press has the duty to engage in coverage of issues causing domestic violence in the society since it has been classified as a global issue against the life and rights of women. It makes the media responsible for being the voice of the voiceless. The social responsibility theory of the press states that though the media should have the freedom to carry out their duties, such duties should have a level of obligations and responsibilities (Nwabueze 2012). McQuail (2005) writes that while it is necessary for the press to be free, the public also have the right to a free press and the right of the people takes precedence. Justifying the responsibility of the media; the theory holds that the press has a right to criticize negative actions in society. Drawing from this position of the argument, it is the duty of the media to identify the causes of domestic violence against women for the societal liberation of domestic violence. This means that the media should identify all customs, cultures and values that guarantee and or provide a template for excuses for committing domestic violence against women, condemn them and bring them to ridicule before the public. Relating this theory to the study, the newspapers are socially responsible to the public; they have the obligation to objectively inform the public the cases of domestic violence and its leading causes with a view to provide an end to it uniquely within the lockdown period. As the voice of the voiceless, media has the duty to wage war against all kinds of domestic violence against women. It is the view of the researcher that identify the causes of domestic violence, exposing those cultures and customs that encourage them and ridiculing them through media interpretation can go a long way in reducing the rate at which it occurs in the society.

\section{Agenda-Setting theory}

Despite being a theory in progress, the proponents of the agenda-setting theory of mass communication maintain that through effective and repeated reporting of an issue in the focal points of the news media, the people will get to know about the activity and possibly act in line with the media directives on such development. This theory makes the mass media critical opinion controller and directors of public views and discourse on prevailing issues around the world. The import of this is that if the increasing rate of domestic violence gets frequent reports in the news media, soon, it will command the attention of the media audience. In doing so, the media reports could force the audience to device means of restricting domestic violence. This is because of the dangers it portends to the individual victims, the family and the society at large which the media expose to the public. This is because, the mass media can produce a change of the cognitive structures, and the perception that the public has about what is happening around them (La Rocca, (2017). The media's ability in doing this according to Agudosy and Ikegbunam (2020) rests in their strength of not only bringing events closer to the people but in drawing their attention to their preferred events which otherwise would have been far away from them. Through bringing these events close to the people, media can then, provide a frame of interpretation to enable their users read and understand what is happening. 
Relating this theory to the current study, media interpretation of domestic violence must provide the direction of opinion and action against it. If the media offer a contrary analysis of the cultures in some societies that aide the commitment of domestic violence against women in the negative light, such analyses must impact on the people and possibly change the rate at which domestic violence thrives in the society.

\section{METHODOLOGY}

Considering the nature of the study, Content Analysis was used as the study method to help the researcher in achieving the research objectives. The population of the study comprises of all publications of Daily Sun, Vanguard and Guardian newspapers from March $23^{\text {rd }}$ to June, 2020. These months covered a total of 100 days in the lockdown period. It means that 100 publications of the three newspapers under investigations were covered within the period since all the three papers are daily publications. This amounts to 300 editions in all. The three newspapers were selected based on accessibility and wide circulation in the country. The manifest contents of the selected papers for the period of study were explored from every single publication of the hard copies. In contrast, the researcher reviews the online versions of the publications using such keywords as couple violence, domestic violence, family violence, husband violence and wife violence.

Given that 300 editions of the three newspapers were manageable, a census study of all the editions of the newspapers was conducted. The researcher's adoption of census study was informed based by Asemah, Gujbawu, Ekhareafo, and Okphanachi, (2012) assertion that census is attractive for small and manageable populations. On this note, all the editions of the newspapers under investigation published within the period of the lockdown were examined and their contents concerning domestic violence were all analyzed.

\section{Unit of analysis}

The unit of analysis for this study is the placement of stories, frequency of the publications, source of interventions and follow-ups. The content categories are front page, inside page, inside page center spreads and back page stories for placement. The domestic violence interventions from the government, NGOs, Human rights and ministry of women affairs are categorized for interventions sources. The study also looked at the frequency of publications using the numbers of stories published within the months under investigation. Stories that are published in the front page are categorized as front page like-wise those published at the back page, inside page and inside page center spreads. Contents that showcase the actions of the government in curbing and rescuing domestic violence victims are classified as government intervention. In contrast, contents that reveal the activities of NGOs, Human rights and ministry of women affairs on their efforts to curtail, help out or rescue victims of domestic violence are classified in like manners. Further, the researcher categorizes contents on the activities into follow-up and not follow-ups. Stories that are reported and followed in subsequent reports are classified as followed-up stories and those that are flashed once without any further review were seen as not followed-up.

\section{The instrument of data collection}

The Coding Sheet, however, was used as an instrument to generate data on the manifest contents of the reports in the selected newspapers on domestic violence against women during the lockdown. The coding guide also was used to provide a guide on the units of analysis and contents categories that the researcher is interested in. 
Volume 1 Number 2

Inter-coder reliability: To ensure that the instrument is reliable, the researcher adopted the Holsti's inter-coder reliability formula. The inter-coder reliability is accepted as the correlation coefficient is up to .72 .

Inter-coder reliability was assessed using Holsti's inter-coder reliability formula. The Holsti's inter-coder reliability test was calculated thus:

Reliability

$$
\mathrm{R}=\frac{2(\mathrm{M})}{\mathrm{N} 1+\mathrm{N} 2}
$$

Therefore Inter-coder reliability

$$
\begin{array}{r}
\mathrm{R}=\frac{2(12) \quad 24}{18+15=33} \\
=0.72
\end{array}
$$

\section{Method of data presentation}

Data from the investigation were presented in tables and simple percentages given the fact that the study is concerned with the examination of the manifest contents of newspapers on domestic violence against women during this global lockdown.

Table 1: Placement of stories on domestic violence against within the lockdown period

\begin{tabular}{llll|l|l} 
Variables & $\begin{array}{l}\text { Daily } \\
\text { sun }\end{array}$ & Vanguard & Guardian & Frequency & Percentage \\
Front page stories & 4 & 7 & 3 & 14 & 12.1 \\
Inside page stories & 21 & 20 & 25 & 66 & 57.3 \\
Inside page center spread & 9 & 10 & 7 & 19 & 22.6 \\
Back page stories & 2 & 4 & 3 & 9 & 7.8 \\
Total & 36 & 41 & 38 & 115 & 100
\end{tabular}

Source: researcher's content analysis 2020

This table shows the kind of attention given to domestic violence by the newspapers under investigation. The number of stories published in the back page, front page and inside page center spread collectively is $42.7 \%$ of the total stories while the ones published inside the page stories account for $57.3 \%$. This means that the media in Nigeria pay less attention to domestic violence against women during the lockdown period.

Table 2: Media portrayal of sources of interventions for victims of domestic violence

\begin{tabular}{lllll|l|} 
Variables & Daily sun & Vanguard & Guardian & Frequency & $\%$ \\
Government intervention & 7 & 8 & 5 & 20 & 17.3 \\
NGO intervention & 12 & 14 & 11 & 37 & 32.1 \\
Human rights & 10 & 14 & 11 & 35 & 30.4 \\
Ministry of women affairs & 7 & 5 & 11 & 23 & 20 \\
Total & 36 & 41 & 38 & 115 & 100
\end{tabular}

Source: Researcher's contents analysis, 2020

From the data available, the most dominant source of intervention on domestic violence against women is the non-Governmental Organizations' efforts in the control of domestic violence against women. This was followed by the human rights efforts in this direction. This implies that the government gets less information on domestic violence to act on perhaps because of the prevailing cultures in various lands and climes that prohibit women from exposing some of the dastardly acts against them by their husbands. 
Volume 1 Number 2

Table 3: Frequency of coverage of domestic violence cases within the lockdown through the frequency of their publications

\begin{tabular}{llll|l|l} 
Variables & Daily sun & Vanguard & Guardian & Frequency & Percentage \\
March & 4 & 3 & 4 & 11 & 20.8 \\
April & 11 & 16 & 13 & 40 & 48.6 \\
May & 13 & 8 & 9 & 30 & 22.6 \\
June & 8 & 14 & 12 & 34 & 7.8 \\
Total & 36 & 41 & 38 & 115 & 100
\end{tabular}

Source: Researcher's contents analysis, 2020

From the data in this table, it can be seen that the newspapers under investigation did not report domestic violence frequently within the period of lockdown. There are total of 100 days and more within the period, yet the total number of stories published in the newspaper was 115 . This implies that as domestic violence against women increases, the media reports on the incidences decreases. A normal news report that can serve as a better reflection of domestic violence against women within the period would have had an increasing number of items as the lockdown lasts.

Table 4: Whether Newspapers follow-up stories on domestic violence during the lockdown

Variables

Daily sun Vanguard Guardian $\mid$ Frequency $\mid$ Percentage

Stories followed up

Stories not followed up

5(13.9) $\quad 11(26.8) \quad 7(18.4)$

$31(86.1) \quad 30(73.8)$

31(81.6)

$36 \quad 41$

38

23
92
115

20

80

100

Source: Researcher's content analysis, 2020

This table revealed the negligence of the media to domestic violence in Nigeria. Of the three 115 publications observed and analyzed in this study, only $20 \%$ were followed up by the media. The remaining $80 \%$ were fresh news stories some of which were published in passing by the press. The reason for this result may form the bases of another research.

\section{DISCUSSION OF FINDINGS}

With $12.1 \%$ and $7.8 \%$ publications on the focal points of the newspapers, this study found that the news papers in Nigeria do not give prominent to coverage of domestic violence in Nigeria. The focal points of the newspapers according Nwabueze, (2011) provides the news stories the ample opportunities to be read by almost all the people that came across the newspapers. This finding goes contrary to the agenda setting theory of mass communication which in the words of Miller (2002), posits that the media lead the public in assigning relative importance to various public issues by positioning them in focal points. In keeping with the agenda-setting functions of the mass media, publishing domestic violence against women in the front and back pages of the newspapers using critical interpretative frames will impact on the audience perception of the crime. Until the domestic violence against women is reported in the media in a language that will jettison the act and all its supporting cultures or agencies, the society will forever remain with the crime. Drawing from the views held in Nwabueze and Oduah (2013), all forms of domestic violence can best be fought if ridiculed in the media for the public to see. This study has shown that the media fail short of the responsibility placed on them by the social responsibility theory. It is their responsibility to ascribe meaning to events through interpretations of issues surrounding such activities for the public to see (Okugo, Onwukwe, Ihechu \& Okereke, 2015) 
The second research question which sought to identify major source of intervention in cases of domestic violence in Nigeria, the investigation revealed that the NGOs are the major intervening bodies with $32.1 \%$ of the total contents observed and analyzed. This finding shows the level of concern given to domestic violence by NGOs. The finding also reveals low level of government attention to domestic violence and related offences in the country as the main reason for persistence of such offences and acts among the people. It however, shows the position of domestic violence on the scale of fundamental human rights.

The data from the third research question seeking to verify whether the media did well by issuing frequent report of domestic violence against women, the researcher found that the media failed to report more on domestic violence within the period under study despite the increase of such acts and crimes within the period. This finding corroborates earlier finding by earlier media scholars that domestic violence is usually under-reported (Daniel, Aniekeme and Nnamdie, 2019). It is a fall out of the media on the social responsibility theory which sees the press as the voice of the voiceless in the society (Ekeli, 2008, p. 338; Agudosy, Ikegbunam and Obiakor, 2018). By virtue of the level of vulnerability, the women and girl children are susceptible to different kinds of dangers especially during war, natural hazards like hurricane, earthquake, and global pandemic like this.

The fourth research question investigated if the newspapers followed their reports up as events unfolds. The data from table four demonstrated that the while $20 \%$ of the news stories published on domestic violence were followed up, $80 \%$ were not followed up. This finding is in tandem with the views of proponents of vulture-reporting-hypothesis. It was the views of the proponents that the media are usually interested in breaking the news with little or no attention to details after the jinx are broken. Lack of follow-up against domestic violence against women contributes to the reason why victims hardly get justice. This finding agrees with that of Uguwanyi, (2018) who concluded that once follow-up were not staged, there will be absolute lack of thematic analysis of events which creates windows for the perpetrators of crimes to go scot free. Lack of follow-up on domestic violence against women translates to violations of expectations of the public. This study lends credence to Raji (2019) who argues that once the media expose the unhealthy behaviours of people in their publications, their audience may, with time learn to take the right attitudinal change to suit the required behavior expected of them. With these kinds of coverage, attitudinal change for the better is not forthcoming anytime soon.

\section{CONCLUSION}

Drawing from the data, it is concluded that the media failed to give adequate and prominent coverage to domestic violence in Nigeria within the lockdown period. The study concludes that as domestic violence is on the increase, media reports on it in Nigeria are decreasing. The necessary media services to the people is generally lacking in their reports on domestic violence. This is because of the media negligence of the need to follow-up their stories. For lack of follow-ups, the thematic details of domestic violence against women were in short supply. This simply means that change of attitude can hardly be obtained so as to reduce the level of domestic violence in the country. Generally, the media violated the expectation of the public who believed them to be the voice of the voiceless.

\section{RECOMMENDATIONS}

Drawing from the data discussed above, the researcher recommended that:

$>$ The mass media should as a respect to their social responsibility functions expose the people to the harmful effects of domestic violence against women in the country. This 
can best be done through publishing issues and activities of victims and perpetrators in the focal points of their newspapers.

$>$ The government should as a matter of responsibility pay attention to domestic violence response especially within this lockdown period.

$>$ The media should encourage adequate coverage of domestic violence against women to suit their social responsibility to the vulnerable group. It is through adequate publication that the media can get it right in setting-agenda on the ills of domestic violence against women in Nigeria.

$>$ The mass media should as a matter of necessity follow-up their stories on domestic violence against women. Following up will help them to provide thematic analysis that can help the people to adopt the change of attitude to reduce violence against women.

\section{REFERENCES}

Agudosy, F. I. and Ikegbunam, P. C. (2020). Managing or Encouraging Discrimination in the Media: Examining Newspapers Reports on Fulani Herdsmen Activities in Select Newspapers. IOSR Journal of humanities and social sciences 4 (8) pp: 2156-2172

Agudosy, F. I., Ikegbunam P. C. and Obiakor, C. U. (2018). Nigerian Newspapers' Coverage of President Buhari's ill Health. The Nigerian Journal of Communication (TNJC). 15 (2) Pp 335-346

Albana, M. S. (2017). Media Reporting On Domestic Violence Against Women In Republic Of Albania. European Journal of Research in Social Sciences 5 (4), ISSN 2056-5429. Accessed on 23 May, 2020 from https://www.idpublications.org/wpcontent/uploads/2017/06/Full-Paper-MEDIA-REPORTING-ON-DOMESTICVIOLENCE-AGAINST-WOMEN-IN-REPUBLIC-OF-ALBANIA.pdf

Asemah, E.S; Gujbawu, M.; Ekhareafo, D.O. and Okphanachi, R.A. (2012) Research Methods and Procedures in Mass Communication. Jos: Great Future Press

Carll, E. K. (2003). News portrayal of violence and women: Implications for public policy. American Behavioral Scientist, 46(12), 1601-1610. doi: 10.1177/0002764203254616

Cripps, K., \& Davis, M. (2012). Communities working to reduce Indigenous family violence. Sydney: Indigenous Justice Clearinghouse.

Daniel, C. A., Aniekeme, O. I. and Nnamdie, U. K. (2019). Uyo Residents' Perception of Selected Newspaper Coverage Of Gender-Based Violence In Nigeria. International Journal of International Relations, Media and Mass Communication Studies Vol.5, No.5, pp.41-55, November 2019 Published by ECRTD- UK Print ISSN: 2059-1845, Online ISSN: $2059-1853$

Domestic Violence Death Review Team. (2015). A report of the NSW domestic violence death review team. Sydney: NSW Government Department Attorney General and Justice

Easteal, P., Holland, K., \& Judd, K. (2015). Enduring themes and silences in media portrayals of violence against women. Women's Studies International Forum, 48, 103-113. doi: 10.1016/j.wsif.2014.10.015 
Ekeli, E. O. (2008). Mass media ethics, peace building and reconciliation. In E. M. E. Mojaye, E. Arahgba, O. Soola \& L. Oso (Eds.), Media dialogue, peace building and reconciliation: Conference proceedings (pp 336-344). Ibadan: ACCE and Book Wright Nigeria.

Flood, M., \& Pease, B. (2009). Factors influencing attitudes to violence against women. Trauma, Violence, \& Abuse, 10(2), 125-142

Fraser, E (2020). Impact of Covid-19 pandemic on violence against women and girls. VAWG Helpdesk research report no 284 VAWG Helpdesk, London.

Galvão, L. A. (2015). Reporting on Violence against Women: A Case Study of Select News Media in Seven Countries in Latin America and the Caribbean. Institutions for Development Sector Institutional Capacity of the State Division Discussion Paper NoIDB-DP-426.

Graham-Harrison, E. A., Glufrrida, H. S. and Ford, L. (2020).Lockdown Around the World Bring Rise In Domestic violence, The guardian 28 March.

Independent Advisory Group on Country Information (IAGCI) (2016). Country Information and Guidance Nigeria: Women fearing gender-based harm or violence

La Rocca, G. (2017) Media, migrants and human rights, International Review of Sociology, 27:2, 225-229, DOI: 10.1080/03906701.2017.1329003 ISSN: 0390-6701 (Print) 14699273 (Online) Journal homepage: http://www.tandfonline.com/loi/cirs20

Lennard, N. (2020). Domestic violence is on the rise with Coronavirus lockdown. The responses are missing the points.

McQuail, D. (2005). McQuail's Mass Communication Theory. (5th ed.). London: Sage

Miller, K. (2002).Communication Theories, Perspectives, Processes and Contexts. Boston. Mcgraw Hill.

National Domestic Violence Hotline NDVH (2020). A snapshot of domestic violence during covid $195^{\text {th }}$ June.

Nwabueze, C. \& Oduah, F. (2013). Media re-victimization of rape victims in a shame culture? Exploring the framing and representation of rape cases in Nigerian dailies. Global Media Journal, 73 (24).pp.1-20 accessed online on 23rd May, 2020 http://www.globalmediajournal.com/open-access/media-revictimization-of-rapevictimsin-a-shame-culture-exploring-the-framing-and-representation-of-rape-cases-innigeriandailies.Pdf

Nwabueze, C. (2011). Magazine and newspaper management and production: An introductory text. Owerri: Top shelve publishers.

Nwabueze, C. (2012). Evaluating the application of social responsibility theory in developing societies. In N.T. Ekeanyanwu, S.N. Ngoa \& I. A. Sobowale (Eds.),Critique and application of communication theories. Ota: Convent University. 
Okugo, C. U., Onwukwe, D. C., Ihechu, I. N. \& Okereke, O. (2015). Child trafficking as a Survival Mechanism in an Economy in Dire Straits: Implication for framing in the Nigerian media. Communication, society and the Nigerian child: issues and emerging trends in the $21^{\text {st }}$ century. Book chapter 22 pp-265-276.

Owusu-Addo, E., Owusu-Addo, S. B., Antoh, E. F., Sarpong, Y. A. Obeng-Okrah, K. and Annan, G. K. (2018). Ghanaian media coverage of violence against women and girls: implications for health promotion.

Quadara, A., \& Wall, L. (2012). What is effective primary prevention of sexual assault? Translating evidence for action. Melbourne: Australia Centre for the Study of Sexual Assault.

Raji, R. A. (2019). Analysis of Nigerian Newspapers' Coverage f International Day f The Girl Child (2012-2016). An M.Sc dissertation submitted to the Department of Mass Communication, Faculty of Social Sciences, Chukwuemeka Odumegwu Ojukwu University, Igbariam campus.

Rollè, R., Abbà, S., Fazzino, R. Marino, E. and Brustia, P. (2014). Domestic violence and newspaper: an explorative study. Available online at www.sciencedirect.com. Department of Psychology, University of Torino, Via Po 14, Torino 10123, Italy.

Sambe, J. A. (2015). Emerging development in political communication in Nigeria. In O. F. Ike \& Udeze, S. E. (eds.). Emerging trends in Gender, Health \& Political Communication in Africa. Enugu, Nigeria. Rhyce Kerex. pp. 113-144.

Sutherland, G., McCormack, A., Pirkis, J., Easteal, P. and Vaughan, C. (2015).Media representations of violence against women and their children: State of knowledge paper. ISSN: 2204-9657 (print) 2204-9665 (online)ISBN: 978-1-925372-19-9 (print) 978-1925372-18-2 (online).

Talabi, F. (2016) Newspaper Reportage of Housewives' Abuse in the Punch andVanguard Newspapers from January to June, 2016. AKSU Journal of Communication Research Vol. 2, No. 2, pp. 130-146

Townsend, M. (2020). Domestic abuse cases soar as lockdown takes its toll some charities can no longer effectively support women because of lockdown and staff sickness.

Ugwuanyi, J. C. (2018). Newspaper Coverage of Rape Cases in Nigeria: Do Newspaper Report Set Agenda on the Issue? International Journal of Communication: an Interdisciplinary journal of Communication studies. A publication of Communication Studies Forum, Department of Mass Communication, University of Nigeria, Nsukka. eISSN: 2630-6735

UN women, (2020). Covid 19 and violence against women and girls: addressing the shadow pandemic. Covid 19 response. Policy brief no 17.

UN, (2020). UN chief decries horrifying rise in domestic violence amid virus lockdown. 
United Nations. (1993). Declaration on the Elimination of Violence against Women (UN Resolution 48/104). Paper presented at the proceedings of the 85th plenary meeting, United Nations General Assembly, Geneva.

Vanguard (2016). Women lawyers offer to fight violence against women, children, 27 May 2016http://www.vanguardngr.com/2016/05/women-lawyers-offer-fight-violencewomen-children/. Accessed on $24^{\text {th }}$ April, 2020.

VicHealth. (2007). Preventing violence before it occurs: A framework and background paper to guide the primary prevention of violence against women in Victoria. Melbourne: Victorian Health Promotion Foundation.

Wikipedia (2020). The impact of the Covid 19-20 Coronavirus pandemic on domestic violence

World Health Organization. (2013). Global and regional estimates of violence against women: Prevalence and health effects of intimate partner violence and non-partner sexual violence. Geneva: WHO.

Yusuf, O., Arulogun, O., Oladepo, O. and Olowokeere, F. (2011) Physical Violenceamong Intimate Partners in Nigeria: A Multi level Analysis. Journal of Public Health and Epidemiology, Vol. 3, pp. 240-247. 